\title{
Chemical inhibition of DNA repair kinases as a promising tool in oncology
}

\author{
Kamila Durisova, Barbora Salovska, Jaroslav Pejchal, Ales Tichy
}

\begin{abstract}
Background. DNA repair pathways play a major role in tumour resistance towards chemo- and radiotherapy. Therefore, inhibitors of specific DNA repair pathways might be advantageous when used in combination with DNA-damaging agents, such as ionizing radiation. This review put particular emphasis on the key DNA repair enzymes: DNA-dependent protein kinase (DNA-PK), ataxia-telangiectasia mutated kinase (ATM) and ATM-Rad3-related kinase (ATR) and their specific inhibitors in the context of radio-sensitization.

Results. We reviewed recent studies on novel and potent inhibitors and found evidence that inhibitors of DNA repair pathways such as small molecule inhibitors could be efficient and selective in tumour cells. Interpretation of recent literature results accompanied with implications for practice and further research are presented.

Conclusions. The prospects of targeting DNA repair enzymes to treat cancer are optimistic, but future work will show if this approach has a significant in vivo efficacy, since we are still waiting for the inhibitor which would pass all phases in clinical trials. In spite of the fact that a number of drugs possess interesting synergy of radiotherapy in vitro, the future use will depend on developing compounds with improved solubility and the serum half-life. Normal tissue toxicity leading to a significant increase of radiotherapy efficiency remains a key question that might be answered only by clinical trials.
\end{abstract}

Key words: DNA repair; inhibitor; DNA-PK; ATM; ATR; ionising radiation

Received: November 12, 2014; Accepted with revision: September 10, 2015; Available online: October 21, 2015 http://dx.doi.org/10.5507/bp.2015.046

Department of Radiobiology, Faculty of Military Health Sciences in Hradec Kralove, University of Defence in Brno, Czech Republic Corresponding author: Ales Tichy, e-mail: ales.tichy@unob.cz

\section{INTRODUCTION}

Double strand breaks (DSB) are one of the most deleterious lesions in DNA. Unfinished or incorrect DSB repair may lead to a loss of genetic information, genome rearrangement or cell death ${ }^{1,2}$. Thus, the repair control is necessary for the maintenance of genomic stability. Three phosphatidylinositol 3-kinase like protein kinases (PIKKs): DNA-dependent protein kinase (DNA-PK), ataxia-telangiectasia mutated kinase (ATM) and ATMRad3-related kinase (ATR) coordinate DNA damage response (DDR), specifically cell cycle arrest, cell survival and DSB repair ${ }^{3,4}$. Two main pathways are employed in DSB repair: homologous recombination (HR) and nonhomologous end joining (NHEJ).

The initiation of HR and NHEJ depends on the phase of the cell cycle. HR requires a complementary segment from the sister chromatid or the homologous chromosome. For that reason, HR is used mainly in the S and G2 phases whereas NHEJ rejoins broken ends together without a homologous sequence, therefore it is predominant in the G0 and G1 phases ${ }^{2,5}$. This carries an enormous risk of creating irrelevant joints and consequently an increasing number of mutations in DNA ( ref. $^{6}$ ).

At the beginning of HR, the MRE11-RAD50-NBS1 complex provides a single stranded DNA (ssDNA) resection to form 3 ' tail'. RAD52 binds to ssDNA and cooperates with replication protein A (RPA) to promote an effective binding of ssDNA with RAD51 (ref. ${ }^{8,9}$ ). Afterwards, RPA is removed by the BRCA2/PALB2 com- plex and displaced with the RAD51 protein ${ }^{7}$. RAD51 catalyses a strand exchange, by which the damaged DNA gets into the intact homologous DNA duplex and forces out one strand as the D-loop (displacement-loop) (ref. ${ }^{10}$ ). The formed molecule contains a hetero-duplex region bound by two branched structures called Holliday junctions, which can migrate and therefore a final product with or without crossing over is formed ${ }^{11,12}$.

The crucial component of NHEJ is DNA-PK, which consists of DNA-dependent protein kinase catalytic subunit (DNA-PKcs) and DNA end binding proteins Ku70/ $\mathrm{Ku} 80\left(\right.$ ref. $\left.^{13}\right)$. The heterodimer Ku70/80 serves as a DSB sensor and recruits DNA-PKcs to the site of DSB in order to form the active DNA-PK complex ${ }^{13-17}$. Once DNAPKcs is in contact with free DNA ends, it is activated by autophosphorylation at Ser 2056 and Thr 2609 (ref. ${ }^{18,19}$ ). Afterwards, DNA ligase IV cooperates with X-ray cross complementing protein (XRCC4) and rejoins broken DNA ends ${ }^{20}$.

When DSB are formed, a chromatin structure is relaxed permitting intermolecular phosphorylation of ATM at Ser 1981. ATM autophosphorylation causes disorganization of an inactive dimer to an active monomer. Other phosphorylations occur at Ser 367 and Ser 1893 (ref. ${ }^{21,22}$ ). ATM phosphorylates a plethora of down-stream targets, which are associated with regulation of the cell cycle, DSB repair and apoptosis, such as BRCA1, p95/NBS1, p53, MDM2, CHK1, CHK2, RAD17, BLM, SMC1, 53BP1 and MDC1 ( ref. $^{22,23}$ ). 
The essential role of ATR is regulation of the cell cycle progression to the $\mathrm{G}_{2}$ phase via phosphorylation of $\mathrm{CHK} 1$ at Ser 367 and 345 (ref. ${ }^{24}$ ). After activation, CHK1 is released from chromatin in order to phosphorylate other substrates such as CDC25A phosphatase. Phosphorylated CDC25A is inactive and therefore unable to activate cyclin dependent kinase 2 (CDK2). Thus, it results into the cell cycle arrest ${ }^{24,25}$. This process is required for correct coordination of DNA replication ${ }^{26}$.

Nearly two-thirds of all cancer patients receive some type of radiotherapy employing ionizing radiation (IR) which induces DSB. The majority of tumours treated by IR or by chemotherapeutics are resistant to anti-cancer therapy and the effect of this treatment is attenuated by enhancement of DNA repair processes in tumour cells. The effort to prevent DDR in tumour cells is driven by the fact that DNA repair inhibition leads to accumulation of DNA damage and subsequent induction of apoptosis. Thus, blocking DDR has been proposed as a promising therapeutic strategy for cancer treatment and it is the rationale for using PIKKs inhibition in the context of cancer treatment.

This paper is focused on small molecule inhibitors targeting one of the key kinase groups involved in DNA repair, PIKKs. We bring a comprehensive overview of inhibitors, which can increase cytotoxic effects due to inhibition of DNA repair. These inhibitors have been recently developed and they have been investigated as potential radio- and chemo-sensitizers. Some inhibitors with high $\mathrm{IC}_{50}$ were also involved in this review since they represent the most important milestones in the development of recent ones.

\section{DNA-PK INHIBITORS}

One of the first developed DNA-PK inhibitors was wortmannin ((1alpha,11alpha)-11-(Acetyloxy)-1(methoxymethyl)-2-oxaandrosta-5,8-dieno(6,5,4-bc)furan$3,7,17$-trione) which is a steroidal fungal metabolite ${ }^{27}$. Arcaro et al. showed that wortmannin could be used for inhibition of phosphatidylinositol 3,4,5-trisphosphate formation with $\mathrm{IC}_{50}: 5 \mathrm{nM}$ and also inhibition of phosphatidylinositol 3-kinase (PI3-K) by binding to Lys-802 at the p110 catalytic subunit (inhibition of DNA-PK with $\mathrm{IC}_{50}$ : $200 \mathrm{nM})\left(\right.$ ref. $\left.^{28,29}\right)$. Wortmannin was unstable in aqueous solutions. It had the half-life shorter than $5 \mathrm{~h}$ in tissue culture medium, therefore, it caused only a reversible growth arrest and cells exited in the $G_{1}$ and $S$ phases after 30 hours $^{30,31}$.

LY294002 (2-morpholino-8-phenyl-4H-1-benzopyran-4-one) is an inhibitor based on naturally occurring flavonoid quercetin ${ }^{32}$, which is structurally unrelated to wortmannin and which inhibits the p110 unit of PI3-K with $\mathrm{IC}_{50}: 1.4 \mu \mathrm{M}$. It was the first inhibitor with specificity against PI3-K (ref. ${ }^{33}$ ). Rosenzweig et al. showed that LY294002 potentiated radiosensitivity and decreased DNA-PK activity, however, ATM kinase was also inhibited by this inhibitor ${ }^{31}$. It has been also reported that LY294002 was capable to inhibit other kinases such as mammalian target of rapamycin (mTOR), casein kinase II (CKII) and PIM-1 (ref. ${ }^{34,35}$ ). Even though LY294002 possessed better stability than wortmannin ${ }^{36}$, a toxicity profile of this compound did not allow its application in clinical trials ${ }^{37}$.

OK-1035, which was revealed by high throughput screening (3-cyano-5-(4-pyridyl)-6-hydrazono-methyl2-pyridone), is a specific inhibitor of DNA-PK with $\mathrm{IC}_{50}$ : $8 \mu \mathrm{M}$ (ref. ${ }^{38,39}$ ). Take et al. determined that OK-1035 did not affect the activity of protein kinase $\mathrm{C}$ (PKC), CDK2, casein kinase I (CKI) or mitogen-activated protein kinase (MAPK) $\left(\right.$ ref. $\left.^{38}\right)$. Nevertheless, it had a low inhibitory ability when p53-wt substrate was used. Stockley et al. synthesized their own OK-1035 inhibitor but with $\mathrm{IC}_{50}$ : $100 \mu \mathrm{M}$, and thus they evaluated OK-1035 as a weak inhibitor. They also showed that OK-1035 did not affect PI3-K and ATM (ref. ${ }^{40}$ ).

Ismail et al. analysed another specific inhibitor of DNAPK revealed by high throughput screening called SU11752 ((Z)-3-(2,4-diethyl-5-((2-oxo-5-(N-phenylsulfamoyl)indolin-3-ylidene)methyl)-1H-pyrrol-3-yl)propanoic acid) with $\mathrm{IC}_{50}: 0.13-0.028 \mu \mathrm{M}$. They used $12 \mu \mathrm{M}$ and $50 \mu \mathrm{M}$ concentrations in experiments and compared them to the effects of wortmannin. SU11752 was more specific to DNA-PK and it did not influence ATM or PI3-K in comparison to wortmannin. However, it did not affect the cell cycle progression in a lower concentration, and it also inhibited other PI3-K related kinases. Moreover, SU11752 is bound very weakly to DNA-PK therefore it is unlikely to be used in clinical trials ${ }^{41}$.

Davidson et al. were focused on IC486241 inhibitor. They observed sensitization of colon cancer cells to irinotecan (topoisomerase I inhibitor) with $\mathrm{IC}_{50}: 1-2$ $\mu \mathrm{M}$. The concentration of $5 \mu \mathrm{M}$ was cytotoxic. On one hand, IC486241 inhibited phosphorylation of DNA-PK at Ser2056, but on the other hand it enhanced HR by increasing the level of RAD51 protein. This inhibitor is believed to be the first specific DNA-PK inhibitor sensitizing breast cancer cells to doxorubicin (topoisomerase II inhibitor) (ref. ${ }^{42,43}$ ).

The IC86621 inhibitor (1-(2-hydroxy-4-morpholin-4-ylphenyl)-ethanone) is a methyl ketone derivative of the DNA-PK inhibitor IC60211 (2-Hydroxy-4-morpholin-4-ylbenzaldehyde) with $\mathrm{IC}_{50}: 120 \mathrm{nM}$. It exhibited no activity against related protein kinases ATM, ATR, CHK1, nor CDK2. Kashishian et al. reported that IC86621 increased cellular toxicity of etoposide (topoisomerase II inhibitor) and bleomycin ${ }^{44}$. Alllen et al. observed that the inhibitor decreased HR and potentiated radiosensitivity of cells in all cell-cycle stages ${ }^{45}$.

IC87102 (2-(4-hydroxybenzoyl)-5-(morpholin-4-yl)phenol; $\mathrm{IC}_{50}: 35 \mathrm{nM}$ ) and IC87361 (5-hydroxy-7-(morpholin4-yl)-2-phenyl-4H-chromen-4-one; $\mathrm{IC}_{50}: 34 \mathrm{nM}$ ) are morphilin derivatives also derived from IC60211 (ref. ${ }^{44,46}$ ). Shinohara et al. found out that these inhibitors increased radiosensitivity of tumour cells, tumour microvasculature and prevented tumour growth ${ }^{47}$. The same group of authors showed that these inhibitors potentiated apoptosis in cancer cells, decreased number of mitotic cells and increased number of cells showing DNA fragmentation ${ }^{46}$. 
Kashishian et al. determined that both inhibitors blocked religation of IR-induced DSB ( ref. $^{44}$ ).

Vanillin (4-hydroxy-3-methoxybenzaldehyde) is naturally presented in the pods of Vanilla planifolia, Vanilla tahitensis and Vanilla pompona ${ }^{48,49}$. Durant et al. reported that Vanillin potentiated the effect of cisplatin in a tumour cell culture model. Vanillin did not influence phosphorylation of $\mathrm{CHK} 2$, which correlated with the fact that it affected only DNA-PK. Additionally, its inhibition increased the number of cells containing RAD51/RPA foci after cisplatin co-treatment. It was also shown that vanillin increased cytotoxicity of trichostatin A (class I and II mammalian histone deacetylases inhibitor) ( ref. $^{50}$ ). However, $\mathrm{IC}_{50}$ of vanillin required for sensitization was higher than $\mathrm{IC}_{50}$ of wortmannin ${ }^{51}$.

LY294002 was used as a template for development of the SF1126 inhibitor ((8S,14S,17S)-14-(carboxymethyl)8-(3-guanidinopropyl)-17-(hydroxymethyl)-3,6,9,12,15pentaoxo-1-(4-(4-oxo-8-phenyl-4H-chromen-2-yl) morpholino-4-ium)-2-oxa-7,10,13,16-tetraazaoctadecan18-oate), NU7026 inhibitor (2-(morpholin-4-yl)-benzo(H) chromen-4-one) and NU7441 inhibitor (2- $N$-morpholino8-dibenzothiophenyl-chromen-4-one) ( ref. $^{52}$ ).

SF1126 is an inhibitor of all isoforms of PI3-K (ref. ${ }^{53}$ ). Ozbay et al. evaluated effects of SF1126 on breast cancer cells. The inhibitor decreased proliferation of the cells, phosphorylation of AKT and induced apoptosis ${ }^{54}$. Mahadevan et al. carried out the phase I clinical trial of SF1126 in patients with solid tumours and B-cell malignancies. SF1126 was well tolerated and did not affect PI3-K activity in the normal tissue. An increase in late apoptosis, a decrease in phosphorylation of AKT and a cleavage of PARP correlating with late apoptosis was apparent $^{55}$.

NU7026, an inhibitor from chromenone library, is a cell permeable, ATP-competitive inhibitor of DNA-PK and ATM, but predominantly affects DNA-PK with $\mathrm{IC}_{50}$ : $0,23 \mu \mathrm{M}, \mathrm{IC}_{50}$ for ATM is more than $100 \mu \mathrm{M}$ (ref. ${ }^{56,57}$ ). Tichy et al. observed the complete growth inhibition of leukemic cells after combination of $10 \mu \mathrm{M}$ NU7026 and the dose of $1 \mathrm{~Gy}$. The level of p53 protein (and its phosphorylated forms) was decreased as well as $\gamma \mathrm{H} 2 \mathrm{AX}$ phosphorylation in the group treated with combination of IR and the inhibitor. It is highly probable that the effect of NU7026 depends on the cell type and the DNA-damaging agent $^{58}$. Willmore et al. demonstrated that $10 \mu \mathrm{M}$ NU7026 maximally potentiated etoposide growth inhibition. The growth inhibition was also observed in combination with idarubicin, daunorubicin, doxorubicin, amsacrine and mitoxantrone (all topoisomerase II inhibitors) (ref. ${ }^{59}$ ). Unlike wortmannin or LY294002, NU7026 had no effect on PI3-K (ref. ${ }^{56}$ ). Cells treated with etoposide and NU7026 showed $\mathrm{G}_{2} / \mathrm{M}$ cell cycle arrest ${ }^{59}$. Nutley et al. determined that NU7026 potentiated the effects of IR, although predominantly after prolonged exposure i.e. 6 or $24 \mathrm{~h}$. Hence, the most intensive effects of NU7026 will be hardly achievable in vivo because the level of NU7026 was undetectable $4 \mathrm{~h}$ after application ${ }^{56}$.

NU7441, another inhibitor from chromenone library, is the most potent and selective inhibitor of DNA-PK so far, with $\mathrm{IC}_{50}: 14 \mathrm{nM}$, it is 100 -fold more selective inhibitor of DNA-PK in comparison to other PI3-K kinases ${ }^{52,60}$. Zhao et al. showed that NU7441 increased cytotoxicity of IR, etoposide and doxorubicin. The loss of $\gamma \mathrm{H} 2 \mathrm{AX}$ foci per a cell was retarded due to NU7441. They also observed the G2/M cell cycle arrest. NU7441 caused a delay of tumour growth in combination with etoposide. The effect of NU7441 was independent on p53 protein status ${ }^{61}$. Tavecchio et al. demonstrated that the inhibitor was also able to influence HR via inhibition of RAD51 protein accumulation $^{62}$. Regrettably, insufficient aqueous solubility is a limiting factor for further usage of this compound ${ }^{61}$.

One of the most promising compounds could be a dual DNA-PK/mTOR inhibitor CC-115. Tsuji et al. observed inhibition of NHEJ and HR pathways by direct inhibition of DNA-PK and indirect inhibition of ATM down-stream molecules such as CHK2 (Thr 68), NBS1 (Ser 343), 53BP1 (Ser 25/29) and SMC1 (Ser 957) (ref. ${ }^{63}$ ). Mortensen et al. reported that CC-115 inhibited proliferation and induced apoptosis in several cell lines. Moreover, the inhibitor exhibited tumour growth inhibition in multiple solid tumour xenografts ${ }^{64}$. CC-115 is in phase I clinical trials now. The goal is to assess the safety and efficacy of the compound employing advanced tumours unresponsive to standard therapies (recruiting, NCT01353625).

In summary, according to preclinical studies, NU7441, IC86621, IC87361, and also CC-115 are among the promising DNA-PK inhibitors and new clinical trials data are expected $^{65}$.

\section{ATM inhibitors}

Caffeine (1,3,7-trimethylxanthine) is a methylxantine with inhibitory effects on ATM ( $\left.\mathrm{IC}_{50}: 0.2 \mathrm{mM}\right)$, ATR $\left(\mathrm{IC}_{50}: 1.1 \mathrm{mM}\right)$ and $\mathrm{mTOR}$. A concentration greater than $10 \mathrm{mM}$ is required to suppress DNA-PK or CHK1 (ref. ${ }^{66,67}$ ). Sarkaria et al. reported that caffeine did not inhibit CHK1 phosphorylation but it inhibited p53 phosphorylation (Ser 15) and also abrogated the $\mathrm{G}_{2} / \mathrm{M}$ checkpoint $^{66}$. Blasina et al. also observed inhibition of CHK2 activation ${ }^{68}$. Unlike other publications, which reported the caffeine-induced ATM inhibition and the $\mathrm{G}_{2} / \mathrm{M}$ checkpoint abrogation, Cortez found surprising hyperphosphorylation of ATM-ATR substrates after caffeine treatment in HCT116 cells and hTERT-RPE1 cells. Moreover, he suggested, although caffeine is an inhibitor of ATM-ATR kinase activity in vitro, it could block the cell cycle checkpoints without inhibiting ATM-ATR activation in vivo ${ }^{67}$.

Hickson et al. identified a new small molecule inhibitor of ATM called KU55933 (2-morpholin-4-yl-6-thianthren-1-yl-pyran-4-one) derived from LY294002 (ref. ${ }^{69}$ ) with $\mathrm{IC}_{50}: 12.9 \mathrm{nM}$. Interestingly, KU55933 was not able to inhibit UV-induced phosphorylation of H2AX (Ser 139), NBS1 (Ser 343), CHK1 (Ser 345) and SMC1 (Ser 966) but it inhibited these phosphorylations after IR treatment together with phosphorylations of CHK2, MDC1, TOPBP1 or BRCA1 at $10 \mu \mathrm{M}$. KU55933 was capable to sensitize HeLa cells towards etoposide, doxorubicin, amsacrine and camptothecin (topoisomerase I inhibitor) $\left(\right.$ ref. $\left.^{70}\right)$. Shaheen et al. reported that the compound itself 
was minimally cytotoxic in prostate cancer cells and it decreased cell survival in combination with IR ( ref. $\left.^{71}\right)$.

An improved ATM inhibitor KU60019 ((2R,6S-rel)2,6-dimethyl- $N$-[5-[6-(4-morpholinyl)-4-oxo-4H-pyran-2yl]-9H-thioxanthen-2-yl-4-morpholineacetamide) is an analogue of KU55933 (ref. $^{72}$ ) with $\mathrm{IC}_{50}: 6.3 \mathrm{nM}$. Golding et al. showed that KU60019 was more water soluble and 3- to 10-fold more potent than his predecessor KU55933. Moreover, it did not influence other 229 kinases and $\mathrm{IC}_{50}$ for DNA-PK and ATR was 270- and 1600-fold higher than for ATM, respectively. The inhibitor was able to inhibit phosphorylations of p53 (Ser 15), H2AX (Ser 139), CHK2 (Thr 68) and AKT (Ser 473) in much lower concentrations after irradiation in comparison to KU55933 (ref. ${ }^{72}$ ). In other tests Golding et al. discovered that KU60019 was even 30-100 times more potent than KU55933 and inhibited phosphorylation of p53 (Ser 15) or H2AX (Ser 139) at $300 \mathrm{nM}$ being stable up to $72 \mathrm{~h}$ in cell cultures ${ }^{73}$. Finally, both inhibitors (KU55933 and KU60019) were shown to be capable of transient ATM inhibition $^{74,75}$.

KU59403 (3-(4-methylpiperazin-1-yl)-N-(6-(6-morpholino-4-oxo-4H-pyran-2-yl)thianthren-2-yl)propanamide) is an improved analogue of KU55933 with better pharmacological properties and greater selectivity and potency against $\mathrm{ATM}$ with $\mathrm{IC}_{50}: 3 \mathrm{nM}$. Batey et al. determined that the concentration necessary for chemo-sensitization is 10 fold lower $(1 \mu \mathrm{M})$ compared to KU55933. They reported that KU59403 at the concentration of $1 \mu \mathrm{M}$ was able to inhibit more than $50 \%$ of ATM activity and potentiated the cytotoxicity of camptothecin, etoposide or doxorubicin. Furthermore, they also observed tumour growth delay after KU59403 treatment in combination with etoposide in mice. The inhibitor maintained a significant concentration in plasma for a longer time in comparison to KU55933. Nevertheless, when administered to mice, the concentration of KU59403 in plasma rapidly decreased ${ }^{69}$.

Additionally, there are other inhibitors of ATM e.g. CP466722 (2-(6,7-dimethoxyquinazolin-4-yl)-5-(pyridin2-yl)-2H-1,2,4-triazol-3-amine) (ref. ${ }^{76}$ ) or CGK733 (2,2-diphenyl-n-(2,2,2-trichloro-1-[3-(4-fluoro-3-nitrophenyl) thioureido]ethyl)acetamide) ( ref. $\left.^{77}\right)$ and the list is not definitive since in the meantime new inhibitors have been synthesized.

\section{ATR inhibitors}

NU6027 (2,6-diamino-4-cyclohexyl-methyloxy-5-nitroso-pyrimidine) was identified as a CDK2 inhibitor ${ }^{78}$. Peasland et al. found out that NU6027 was a more potent inhibitor of ATR $\left(\mathrm{IC}_{50}: 2.8-2.9 \mu \mathrm{M}\right)$ than of CDK2 $\left(\mathrm{IC}_{50}\right.$ : $10 \mu \mathrm{M})$. NU6027 had no effect on phosphorylations of neither DNA-PK nor ATM at $10 \mu \mathrm{M}$ after irradiation and was able to potentiate the effect of hydroxyurea (ribonucleotide reductase inhibitor), doxorubicin, camptothecin, temozolomide, cisplatin and IR. The inhibitor decreased the number of RAD51 foci-positive cells and modestly reduced the amount of $\gamma \mathrm{H} 2 \mathrm{AX}$ foci after PARP inhibitor (PF-01367338) treatment. It also caused synthetic death in combination with the PARP inhibitor or in XRCC1defective cells ${ }^{79}$. Sultana et al. employed EM-C11, EM-
C12 (XRCC1-deficient) and CHKO9 cells (wild type). After NU6027 treatment, XRCC1-deficient cells showed a higher mean tail moment in the Comet assay, a higher amount of $\gamma \mathrm{H} 2 \mathrm{AX}$ foci, $\mathrm{a}_{2}$ arrest and a higher amount of early apoptotic cells when compared to CHKO9 cells. These data confirmed the relationship between ATR and XRCC1, i.e. synthetic lethality ${ }^{80}$. Unfortunately, NU6027 is not water soluble, which is a substantial limitation for further usage ${ }^{79}$.

Schisandrin B (1,2,3,13-tetramethoxy-6,7-dimethyl-5,6, 7, 8-tetrahydrobenzo [3', 4'] cycloocta [ $\left.1^{\prime}, 2 ': 4,5\right]$ benzo[1,2-d][1,3]dioxole) is a dibenzocyclooctadiene derivative isolated from Fructus Schisandrae, which is commonly used in Chinese medicine, with $\mathrm{IC}_{50}: 7.25 \mu \mathrm{M}$ (ref. ${ }^{81,82}$ ). This inhibitor is a mixture of gomisin $\mathrm{N}$ and $\gamma$-schisandrin which are the diastereomers of each other. Tatewaki et al. revealed that gomisin $\mathrm{N}$ was an active form responsible for inhibiting ATR (ref. ${ }^{83}$ ). Nishida et al. observed that Schisandrin B alone had no effect on cell viability. This is in contrast to combined treatment with UV-radiation, which caused the $\mathrm{G}_{2} / \mathrm{M}$ checkpoint abrogation and the decrease in phosphorylations of p53 (Ser 15) and CHK1 (Ser 317). Importantly, this was observed in ATM-deficient cells but not cells with ATR depleted by siRNA ${ }^{82}$. Schisandrin B also potentiated the effect of doxorubicin ${ }^{84}$.

Pollard et al. identified VE-821 (3-amino-6-(4-(methylsulfonyl)phenyl)-N-phenylpyrazine-2-carboxamide) as a selective inhibitor of ATR ( $\left.\mathrm{IC}_{50}: 26 \mathrm{nM}\right)$. VE-821 was able to inhibit CHK1 phosphorylation (Ser 345) and it potentiated the effect of gemcitabine, camptothecin, cisplatin and IR. Pollard also showed that treatment of prostate cancer cells with VE-821 caused higher cell death in comparison to normal cells ${ }^{85}$. Vavrova et al. showed that the combination of VE- 821 and IR in HL-60 cells resulted in a decreased amount of cells in the $G_{2}$ phase, increased apoptosis and a higher amount of $\gamma \mathrm{H} 2 \mathrm{AX}$ foci, which persisted $72 \mathrm{~h}$ after irradiation ${ }^{86}$.

VE-822 (5-(4-(isopropylsulfonyl)phenyl)-3-(3-(4((methylamino)methyl)phenyl)isoxazol-5-yl)pyrazin2-amine) is an analogue of VE-821 with increased potency against ATR $\left(\mathrm{IC}_{50}: 19 \mathrm{nM}\right)$ and better pharmacokinetic properties $^{87}$. Fokas et al. reported that VE-822 was able to enhance the effects of IR and chemotherapy in cancer cells but it did not affect normal cells. VE-822 showed a decrease in phosphorylation of CHK1 at Ser 345 after gemcitabine or radiotherapy. It increased the amount of $\gamma \mathrm{H} 2 \mathrm{AX} / 53 \mathrm{BP} 1$ foci but it did not affect the ATM, CHK2 or DNA-PK activity. VE-822 abrogated the $\mathrm{G}_{2}$ arrest in combination with IR and increased the number of early and late apoptotic cells ${ }^{88}$.

Recently, new ATR selective inhibitors called AZD6738 and AZ-20 (4-[4-[(3R)-3-Methyl-4-morpholinyl]6-[1-(methylsulfonyl)cyclopropyl]-2-pyrimidinyl]-1H-indole) have been discovered. (ref. ${ }^{89}$ ).

Jones et al. reported discovery of a new ATR inhibitor AZD6738 with good pharmacokinetics and properties for oral administration ${ }^{90}$. The inhibitor has been evaluated in three clinical trials. The first one is aimed at assessing the safety, tolerability and appropriate dose of the 
Table 1. Small molecule inhibitors of DNA repair kinases in preclinical or clinical development for cancer therapy.

\begin{tabular}{|c|c|c|c|}
\hline Inhibitor & Specifity & Mono- or combination therapy and Clinical study stage & $\begin{array}{l}\text { Reference or } \\
\text { Clinical trial } \\
\text { identifier }\end{array}$ \\
\hline PI3-K & Wortmannin & $\begin{array}{l}\text { Etoposide, cisplatin in preclinical testing using human glioblastoma cells } \\
\text { Cisplatin in preclinical testing using human ovarian cancer cells }\end{array}$ & $\begin{array}{l}91 \\
92\end{array}$ \\
\hline PI3-K & LY294002 & $\begin{array}{l}\text { Cisplatin in preclinical testing using glioblastoma cells } \\
\text { IR in preclinical testing in vivo }\end{array}$ & $\begin{array}{l}93 \\
37\end{array}$ \\
\hline PI3-K & SF1126 & Phase I clinical trial & NCT00907205 \\
\hline DNA-PK & OK-1035 & IR in preclinical testing using radioresistant L5178Y cells & 94 \\
\hline DNA-PK & SU11752 & IR in preclinical testing using glioblastoma cells & 41 \\
\hline DNA-PK & IC486241 & $\begin{array}{l}\text { SN38, oxaliplatin, cisplatin in preclinical testing using colon cancer cells } \\
\text { Doxorubicin, cisplatin in preclinical testing using breast cancer cells }\end{array}$ & $\begin{array}{l}43 \\
42\end{array}$ \\
\hline DNA-PK & IC86621 & $\begin{array}{l}\text { IR in preclinical testing using DNA-PK }{ }_{\mathrm{CS}} \text { wild-type and defective Chinese } \\
\text { hamster ovary cells } \\
\text { Etoposide, bleomycin in preclinical testing using cancer cell lines }\end{array}$ & 45 \\
\hline DNA-PK & IC87102 & IR in preclinical testing in vivo & 47 \\
\hline DNA-PK & IC87361 & IR in preclinical testing in vivo & 46 \\
\hline DNA-PK & Vanillin & $\begin{array}{l}\text { IR, cisplatin in preclinical testing using cancer cell lines } \\
\text { IR, TSA, cisplatin in preclinical testing using HeLa cells }\end{array}$ & $\begin{array}{l}51 \\
50\end{array}$ \\
\hline DNA-PK & NU7026 & $\begin{array}{l}\text { IR in preclinical testing using gastric cancer cells } \\
\text { IR in preclinical testing using MOLT- } 4 \text { cells }\end{array}$ & $\begin{array}{l}95 \\
58\end{array}$ \\
\hline DNA-PK & NU7441 & $\begin{array}{l}\text { IR, doxorubicin in preclinical testing using breast cancer cells } \\
\text { IR doxorubicin in preclinical testing using MOLT- } 4 \text { cells }\end{array}$ & $\begin{array}{l}96 \\
97\end{array}$ \\
\hline $\begin{array}{l}\text { DNA-PK/ } \\
\text { mTOR }\end{array}$ & CC-115 & Phase I clinical trial & NCT01353625 \\
\hline $\begin{array}{l}\text { ATM/ATR/ } \\
\text { mTOR }\end{array}$ & Caffeine & $\begin{array}{l}\text { Single agent in preclinical testing using human cancer cells } \\
\text { IR, hydroxyurea in preclinical testing using HCT116, hTERT-RPE1 cells }\end{array}$ & $\begin{array}{l}98 \\
67\end{array}$ \\
\hline ATM & KU55933 & $\begin{array}{l}\text { IR in preclinical testing using human mesenchymal stem cells } \\
\text { Doxorubicin in preclinical testing using ATM-defective and normal human } \\
\text { fibroblast cells }\end{array}$ & $\begin{array}{r}99 \\
100\end{array}$ \\
\hline ATM & KU60019 & $\begin{array}{l}\text { Doxorubicin in preclinical testing using breast cancer cells } \\
\text { IR in preclinical testing in vivo }\end{array}$ & $\begin{array}{l}101 \\
102\end{array}$ \\
\hline ATM & KU59403 & $\begin{array}{l}\text { Etoposide, doxorubicin, camptothecin, IR in preclinical testing in vitro } \\
\text { (human cancer cells) and in vivo }\end{array}$ & 69 \\
\hline ATM & CP466722 & IR in preclinical testing using different cell lines & 76 \\
\hline ATM/ATR & CGK733 & Paclitaxel in preclinical testing using HBV-positive hepatocellular cancer cells & 77 \\
\hline ATR/CDK2 & NU6027 & $\begin{array}{l}\text { Hydroxyurea, cisplatin, camptothecin, doxorubicin, paclitaxel in preclinical } \\
\text { testing using MCF-7 cells } \\
\text { Cisplatin in preclinical testing using XRCC1 proficient/deficient Chinese } \\
\text { hamster ovary and human ovarian cancer cells }\end{array}$ & $\begin{array}{l}79 \\
80\end{array}$ \\
\hline ATR & Schisandrin B & $\begin{array}{l}\text { UV in preclinical testing using A549 cells } \\
\text { UV, IR in preclinical testing using different cell lines }\end{array}$ & $\begin{array}{l}83 \\
82\end{array}$ \\
\hline ATR & VE-821 & $\begin{array}{l}\text { IR in preclinical testing using HL-60 } \\
\text { MK-8776, PARP inhibitor (veliparib), topoisomerase I inhibitor (topotecan), } \\
\text { cisplatin, gemcitabine in preclinical testing using ovarian cancer cells }\end{array}$ & $\begin{array}{l}103 \\
104\end{array}$ \\
\hline ATR & $\begin{array}{l}\text { VE-822 } \\
(\text { VX-970) }\end{array}$ & Phase I clinical trial & NCT02157792 \\
\hline ATR & AZ-20 & Single agent in preclinical testing using different cell lines and in vivo & 89 \\
\hline ATR & AZD6738 & Phase I clinical trial & NCT02223923 \\
\hline
\end{tabular}

$\mathrm{ATM}=$ ataxia telangiectasia mutated protein; ATR = ATM- and Rad3-related protein; CDK2 = cyclin dependent kinase 2; DNA-PK = DNA-dependent protein kinase; DNA-PKCS = DNA-dependent protein kinase catalytic subunit; HBV = hepatitis B virus; IR = ionising radiation; $\mathrm{mTOR}=$ mammalian target of rapamycin; PI3-K = phosphatydilinositol-3-kinases; TSA = trichostatin A; UV = ultraviolet light ; XRCC1 = $\mathrm{X}$-ray repair cross-complementing protein 1 . Where no reference is given, information may be found on the ClinicalTrials.gov website. 


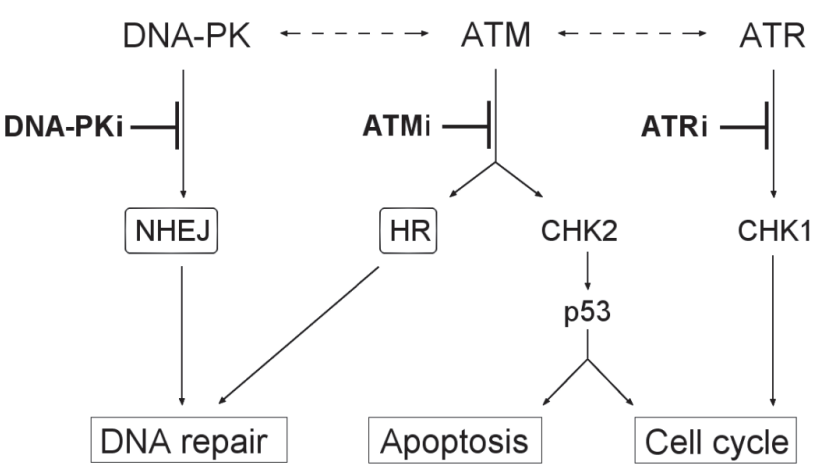

Fig. 1. Scheme of DNA repair kinases inhibition.

Important biological consequences of DNA repair kinases inhibition are shown. DNA-PK phosphorylates DNA ligase IV and/or XRCC4, which may affect their interactions with $\mathrm{Ku}$ and other proteins. Thus, inhibition of DNA-PK abrogates NHEJ and impacts DNA repair similarly to inhibition of ATM, which is a key regulator of HR. ATM is required in the initiation of HR for it phosphorylates number of downstream targets such as H2AX, BRCA1, MRN complex, etc. Therefore, ATM inhibition leads to accumulation of DNA damage, too. Additionally, ATM affects apoptosis and cell cycle progression indirectly via phosphorylation of $\mathrm{CHK} 2$ or directly via phosphorylation of transcriptional factor $\mathrm{p} 53$. The essential role of ATR is regulation of cell cycle progression to the $\mathrm{G}_{2}$ phase via phosphorylation of CHK1. Additionally, mutual cross-talks and interactions of the given kinases have been proved, too.

ATM, ataxia-telangiectasia mutated kinase; ATR, ATM-Rad3related kinase; BRCA1, breast cancer 1 protein; CHK1/2, checkpoint kinase-1/2; DNA-PK, DNA-dependent protein kinase; HR, homologous recombination; MRN, MRE11-Nibrin-RAD50 protein complex; NHEJ, non-homologous end joining

inhibitor. The effect of the inhibitor will be determined in patients with advanced cancer without any anticancer treatment and in patients with advanced cancer, who are treated by radiotherapy (recruiting, NCT02223923). The next clinical study was focused on pharmacokinetics and employed different kind of patients (with CLL, PLL or B cell lymphoma) (completed, NCT01955668). The last one combines AZD6738 with cytotoxic chemotherapy regimens and novel anti-cancer agents e.g. carboplatin (recruiting, NCT02264678).

\section{CONCLUSION}

Current DNA-damaging anti-cancer strategies, including chemotherapy and radiotherapy, are often unsuccessful because the response to these therapies varies among individual patients and is affected by a cross-talk of different signalling pathways. It is far beyond the extent of this paper to describe all other pathways, inhibition of which contributes to increased sensitivity towards IR (e.g. apoptotic or NF-kB signalling pathway). Therefore, the authors of this review focused on DDR and mainly on PIKKs, which are also in the centre of their experimental interest.

The reviewed studies, which use small-molecular DNA repair inhibitors, show in vitro as well as in vivo, that these novel and potent inhibitors could be developed into future drugs, which would selectively kill tumour cells exhibiting deficiencies in particular DNA repair pathways. So far, clinical relevance of the DNA repair inhibitors has not reached the one of PARP or other inhibitors, because this group is still waiting for a compound that would pass all phases of clinical trials. In spite of the fact that a number of drugs possess interesting synergy with radiotherapy in vitro, future use will depend on developing compounds with improved solubility and the serum half-life, which would enhance anti-cancer therapy.

The recently ongoing clinical trials such as those with CC-115, NVP-BEZ235 or NK31 are expected to answer the question on single-agent support of radiation therapy and to open opportunities for other promising radiosensitizers.

\section{ABBREVIATIONS}

ATRIP, ATR interacting protein; ATM, ataxia-telangiectasia mutated kinase; DDR, DNA damage response; ATR, ATM- and Rad3-related protein; DNA-PK, DNAdependent protein kinase; DNA-PK ${ }_{\mathrm{CS}}$, DNA-dependent protein kinase catalytic subunit; DSB, double strand breaks; HR, homologous recombination; IR, ionising radiation; NHEJ, non-homologous end joining; PARP, poly(ADP-ribose) polymerase; p53, TP53 tumour suppressor; RPA, replication protein A; ssDNA, single stranded DNA; TOPB1, topoisomerase (DNA) II binding protein 1 .

Acknowledgement: We would like to thank Eva Drahokoupilova for her help with the English translation.

This work was supported by the Ministry of Defence, the Czech Republic (A long-term organization development plan 1011).

Author contribution: AT: manuscript design; KD: drafting and manuscript writing; all authors: final approval.

Conflict of interest statement: The authors state that there are no conflicts of interest regarding the publication of this article.

\section{REFERENCES}

1. Guirouilh-Barbat J, Huck S, Bertrand P, Pirzio L, Desmaze C, Sabatier L, Lopez BS. Impact of the KU80 Pathway on NHEJ-Induced Genome Rearrangements in Mammalian Cells. Molecular Cell 2004;14(5):61123.

2. Mao Z, Bozzella M, Seluanov A, Gorbunova V. DNA repair by nonhomologous end joining and homologous recombination during cell cycle in human cells. Cell Cycle 2008;7(18):2902-6.

3. Goodwin CB, Yang Z, Yin F, Yu M, Chan RJ. Genetic disruption of the PI3K regulatory subunits, p85a, p55a, and p50a, normalizes mutant PTPN11-induced hypersensitivity to GM-CSF. Haematologica 2012;97(7):1042-7.

4. Shang Z-F, Huang B, Xu Q-Z, Zhang S-M, Fan R, Liu X-D, Wang Y, Zhou $\mathrm{P}-\mathrm{K}$. Inactivation of DNA-dependent protein kinase leads to spindle disruption and mitotic catastrophe with attenuated checkpoint protein 2 Phosphorylation in response to DNA damage. Cancer Res 2010;70(9):3657-66.

5. Rothkamm K, Krüger I, Thompson LH, Löbrich M. Pathways of DNA double-strand break repair during the mammalian cell cycle. Mol Cell Biol 2003;23(16):5706-15. 
6. Bannister LA, Waldman BC, Waldman AS. Modulation of error-prone double-strand break repair in mammalian chromosomes by DNA mismatch repair protein Mlh1. DNA Repair 2004;3(5):465-74.

7. Grabarz A, Barascu A, Guirouilh-Barbat J, Lopez BS. Initiation of DNA double strand break repair: signaling and single-stranded resection dictate the choice between homologous recombination, nonhomologous end-joining and alternative end-joining. Am J Cancer Res 2012;2(3):249-68.

8. Parsons CA, Baumann P, Van Dyck E, West SC. Precise binding of single-stranded DNA termini by human RAD52 protein. EMBO 2000;19(15):4175-81.

9. Sugiyama T, New JH, Kowalczykowski SC. DNA annealing by Rad52 Protein is stimulated by specific interaction with the complex of replication protein $\mathrm{A}$ and single-stranded DNA. Proc Natl Acad Sci U S A 1998;95(11):6049-54.

10. Budke B, Chan Y-L, Bishop DK, Connell PP. Real-time solution measurement of RAD51- and RecA-mediated strand assimilation without background annealing. Nucleic Acids Res 2013;41(13):e130.

11. Schwacha A, Kleckner N. Identification of double Holliday junctions as intermediates in meiotic recombination. Cell 1995;83(5):783-91.

12. Holliday R. A mechanism for gene conversion in fungi. Genet Res 1964;5(02):282-304.

13. Gottlieb TM, Jackson SP. The DNA-dependent protein kinase: requirement for DNA ends and association with Ku antigen. Cel 1993;72(1):131-42.

14. Falck J, Coates J, Jackson SP. Conserved modes of recruitment of ATM, ATR and DNA-PKCs to sites of DNA damage. Nature 2005;434(7033):605-11.

15. Mimori T, Hardin JA. Mechanism of interaction between Ku protein and DNA. J Biol Chem 1986;261(22):10375-9.

16. Falzon M, Fewell JW, Kuff EL. EBP-80, a transcription factor closely resembling the human autoantigen $\mathrm{Ku}$, recognizes single- to doublestrand transitions in DNA. J Biol Chem 1993;268(14):10546-52.

17. Blier PR, Griffith AJ, Craft J, Hardin JA. Binding of Ku protein to DNA. Measurement of affinity for ends and demonstration of binding to nicks. J Biol Chem 1993;268(10):7594-601.

18. Douglas P, Sapkota GP, Morrice N, Yu Y, Goodarzi AA, Merkle D, Meek $\mathrm{K}$, Alessi DR, Lees-Miller SP. Identification of in vitro and in vivo phosphorylation sites in the catalytic subunit of the DNA-dependent protein kinase. Biochem J 2002;368(Pt 1):243-51.

19. Chen BPC, Chan DW, Kobayashi J, Burma S, Asaithamby A, MorotomiYano K, Botvinick E, Qin J, Chen DJ. Cell cycle dependence of DNAdependent protein kinase phosphorylation in response to DNA double strand breaks. J Biol Chem 2005;280(15):14709-15.

20. Grawunder U, Wilm M, Wu X, Kulesza P, Wilson TE, Mann M, Lieber MR. Activity of DNA ligase IV stimulated by complex formation with XRCC4 protein in mammalian cells. Nature 1997;388(6641):492-5.

21. Kozlov SV, Graham ME, Peng C, Chen P, Robinson PJ, Lavin MF. Involvement of novel autophosphorylation sites in ATM activation. EMBO J 2006;25(15):3504-14

22. Tomita M. Involvement of DNA-PK and ATM in radiation- and heatinduced DNA damage recognition and apoptotic cell death. J Radiat Res 2010;51(5):493-501.

23. Ahn JY, Schwarz JK, Piwnica-Worms H, Canman CE. Threonine 68 phosphorylation by ataxia telangiectasia mutated is required for efficient activation of Chk2 in response to ionizing radiation. Cancer Res 2000;60(21):5934-6.

24. Lopez-Girona A, Tanaka K, Chen XB, Baber BA, McGowan CH, Russel $P$. Serine-345 is required for Rad3-dependent phosphorylation and function of checkpoint kinase Chk1 in fission yeast. Proc Natl Acad Sci USA 2001;98(20):11289-94.

25. Liu Q, Guntuku S, Cui XS, Matsuoka S, Cortez D, Tamai K, Luo G, Carattini-Rivera S, DeMayo F, Bradley A, Donehower LA, Elledge SJ. Chk1 is an essential kinase that is regulated by Atr and required for the G(2)/M DNA damage checkpoint. Genes Dev 2000;14(12):1448 59.

26. Hurley PJ, Bunz F. ATM and ATR: components of an integrated circuit. Cell Cycle 2007;6(4):414-7.

27. MacMillan J, Vanstone $A E$, Yeboah SK. The structure of wortmannin, a steroidal fungal metabolite. Chem Commun (London) 1968;(11):6134.

28. Arcaro A, Wymann MP. Wortmannin is a potent phosphatidylinositol 3-kinase inhibitor: the role of phosphatidylinositol 3,4,5-trisphosphate in neutrophil responses. Biochem J 1993;296(Pt 2):297-301.
29. Wymann MP, Bulgarelli-Leva G, Zvelebil MJ, Pirola L, Vanhaesebroeck B, Waterfield MD, Panayotou G. Wortmannin inactivates phosphoinositide 3-kinase by covalent modification of Lys-802, a residue involved in the phosphate transfer reaction. Mol Cell Biol 1996;16(4):1722-33.

30. Kimura K, Hattori S, Kabuyama Y, Shizawa Y, Takayanagi J, Nakamura S, Toki S, Matsuda Y, Onodera K, Fukui Y. Neurite outgrowth of PC12 cells is suppressed by wortmannin, a specific inhibitor of phosphatidylinositol 3-kinase. J Biol Chem 1994;269(29):18961-7.

31. Rosenzweig KE, Youmell MB, Palayoor ST, Price BD. Radiosensitization of human tumor cells by the phosphatidylinositol3-kinase inhibitors wortmannin and LY294002 correlates with inhibition of DNAdependent protein kinase and prolonged G2-M delay. Clin Cancer Res 1997;3(7):1149-56.

32. Imai $Y$, Yamagishi $H$, Ono $Y$, Ueda $Y$. Versatile inhibitory effects of the flavonoid-derived PI3K/Akt inhibitor, LY294002, on ATP-binding cassette transporters that characterize stem cells. Clin Transl Med 2012;1(1):24.

33. Vlahos CJ, Matter WF, Hui KY, Brown RF. A specific inhibitor of phosphatidylinositol 3-kinase, 2-(4-morpholinyl)-8-phenyl-4H-1-benzopyran-4-one (LY294002). J Biol Chem 1994;269(7):5241-8.

34. Brunn GJ, Williams J, Sabers C, Wiederrecht G, Lawrence JC Jr, Abraham RT. Direct inhibition of the signaling functions of the mammalian target of rapamycin by the phosphoinositide 3-kinase inhibitors, wortmannin and LY294002. EMBO J 1996;15(19):5256-7.

35. Gharbi SI, Zvelebil MJ, Shuttleworth SJ, Hancox T, Saghir N, Timms JF, Waterfield MD. Exploring the specificity of the PI3K family inhibitor LY294002. Biochem J 2007;404(1):15-21.

36. Gong C, Liao H, Wang J, Lin Y, Qi J, Qin L, Tian L-Q, Guo F-J. LY294002 induces $\mathrm{G0} / \mathrm{G} 1$ cell cycle arrest and apoptosis of cancer stem-like cells from human osteosarcoma via down-regulation of PI3K activity. Asian Pac J Cancer Prev 2012;13(7):3103-7.

37. Gupta AK, Cerniglia GJ, Mick R, Ahmed MS, Bakanauskas VJ, Muschel RJ, McKenna WG. Radiation sensitization of human cancer cells in vivo by inhibiting the activity of PI3K using LY294002. Int J Radiat Oncol Biol Phys 2003;56(3):846-53.

38. Take $Y$, Kumano M, Hamano $Y$, Fukatsu $H$, Teraoka $H$, Nishimura S, Okuyama A. OK-1035, a Selective Inhibitor of DNA-Dependent Protein Kinase. Biochem Biophys Res Commun 1995;215(1):41-7.

39. Take Y, Kumano M, Teraoka H, Nishimura S, Okuyama A. DNADependent Protein Kinase Inhibitor (OK-1035) Suppresses p21 Expression in HCT116 Cells Containing Wild-Type p53 Induced by Adriamycin. Biochem Biophys Res Commun 1996;221(2):207-12.

40. Stockley M, Clegg W, Fontana G, Golding BT, Martin N, Rigoreau LJ., Smith GC., Griffin RJ. Synthesis, crystal structure determination, and biological properties of the DNA-dependent protein kinase (DNA$\mathrm{PK}$ ) inhibitor 3-cyano-6-hydrazonomethyl-5-(4-pyridyl)pyrid-[1H]2-one (OK-1035). Bioorg Med Chem Lett 2001;11(21):2837-41.

41. Ismail IH, Mårtensson S, Moshinsky D, Rice A, Tang C, Howlett A, McMahon G, Hammarsten O. SU11752 inhibits the DNA-dependent protein kinase and DNA double-strand break repair resulting in ionizing radiation sensitization. Oncogene 2004;23(4):873-82.

42. Davidson D, Grenier J, Martinez-Marignac V, Amrein L, Shawi M, Tokars M, Aloyz R, Panasci L. Effects of the novel DNA dependent protein kinase inhibitor, IC486241, on the DNA damage response to doxorubicin and cisplatin in breast cancer cells. Invest New Drugs 2012;30(4):1736-42.

43. Davidson D, Coulombe Y, Martinez-Marignac VL, Amrein L, Grenier J, Hodkinson K, Masson J-Y, Aloyz R, Panasci L. Irinotecan and DNAPKcs inhibitors synergize in killing of colon cancer cells. Invest New Drugs 2012;30(3):1248-56.

44. Kashishian A, Douangpanya H, Clark D, Schlachter ST, Eary CT, Schiro JG, Huang H, Burgess LE, Kesicki EA, Halbrook J. DNA-dependent protein kinase inhibitors as drug candidates for the treatment of cancer. Mol Cancer Ther 2003;2(12):1257-64.

45. Allen C, Halbrook J, Nickoloff JA. Interactive Competition Between Homologous Recombination and Non-Homologous End Joining. Mol Cancer Res 2003;1(12):913-20.

46. Shinohara ET, Geng L, Tan J, Chen H, Shir Y, Edwards E, Halbrook J, Kesicki EA, Kashishian A, Hallahan DE. DNA-Dependent Protein Kinase Is a Molecular Target for the Development of Noncytotoxic Radiation-Sensitizing Drugs. Cancer Res 2005;65(12):4987-92.

47. Shinohara E, Halbrook J, Geng L, Xia F, Hallahan DE. Radiosensatization by the novel DNA-Dependent Protein Kinase 
(DNA-PK) inhibitors, IC87102 and IC87361 in animal tumor models. AACR Meeting Abstracts 2004;2004(1):310-a.

48. Tamai $K$, Tezuka $H$, Kuroda Y. Different modifications by vanillin in cytotoxicity and genetic changes induced by EMS and $\mathrm{H} 2 \mathrm{O} 2$ in cultured Chinese hamster cells. Mutat Res 1992;268(2):231-7.

49. Jansson $T$, Zech L. Effects of vanillin on sister-chromatid exchanges and chromosome aberrations in human lymphocytes. Mutat Res 1987;190(3):221-4.

50. Yaneva M, Li H, Marple T, Hasty P. Non-homologous end joining but not homologous recombination, enables survival for cells exposed to a histone deacetylase inhibitor. Nucleic Acids Res 2005;33(16):5320-30.

51. Durant S, Karran P. Vanillins-a novel family of DNA-PK inhibitors. Nucleic Acids Res 2003;31(19):5501-12.

52. Leahy JJJ, Golding BT, Griffin RJ, Hardcastle IR, Richardson C, Rigoreau L, Smith GCM. Identification of a highly potent and selective DNAdependent protein kinase (DNA-PK) inhibitor (NU7441) by screening of chromenone libraries. Bioorg Med Chem Lett 2004;14(24):6083-7.

53. Garlich JR, De P, Dey N, Su JD, Peng X, Miller A, Murali R, Lu Y, Mills GB, Kundra V, Shu H-K, Peng Q, Durden DL. A Vascular Targeted Pan Phosphoinositide 3-Kinase Inhibitor Prodrug, SF1126, with Antitumor and Antiangiogenic Activity. Cancer Res 2008;68(1):20615.

54. Ozbay T, Durden DL, Liu T, O’Regan RM, Nahta R. In vitro evaluation of pan-PI3-kinase inhibitor SF1126 in trastuzumab-sensitive and trastuzumab-resistant HER2-over-expressing breast cancer cells. Cancer Chemother Pharmacol 2010;65(4):697-706.

55. Mahadevan D, Chiorean EG, Harris WB, Von Hoff DD, Stejskal-Barnett A, Qi W, Anthony SP, Younger AE, Rensvold DM, Cordova F, Shelton CF, Becker MD, Garlich JR, Durden DL, Ramanathan RK. Phase I pharmacokinetic and pharmacodynamic study of the pan-PI3K/mTORC vascular targeted pro-drug SF1126 in patients with advanced solid tumours and B-cell malignancies. Eur J Cancer 2012;48(18):3319-27.

56. Nutley BP, Smith NF, Hayes A, Kelland LR, Brunton L, Golding BT, Smith GCM, Martin NMB, Workman P, Raynaud FI. Preclinical pharmacokinetics and metabolism of a novel prototype DNA-PK inhibitor NU7026. Br J Cancer 2005;93(9):1011-8.

57. You $H$, Kong $M$, Wang $L$, Xiao $X$, Liao $H$, Bi Z, Yan $H$, Wang $H$, Wang $C$, Ma Q, Liu Y, Bi Y. Inhibition of DNA-dependent protein kinase catalytic subunit by small molecule inhibitor NU7026 sensitizes human leukemic K562 cells to benzene metabolite-induced apoptosis. J Huazhong Univ Sci Technol Med Sci 2013;33(1):43-50.

58. Tichý A, Novotná E, Durisová K, Salovská B, Sedlaríková R, Pejchal J, Zárybnická L, Vávrová J, Sinkorová Z, Rezácová M. Radio-sensitization of human leukaemic molt-4 cells by DNA-dependent protein kinase inhibitor, NU7026. Acta Medica (Hradec Kralove) 2012;55(2):66-73.

59. Willmore E, de Caux S, Sunter NJ, Tilby MJ, Jackson GH, Austin CA Durkacz BW. A novel DNA-dependent protein kinase inhibitor NU7026, potentiates the cytotoxicity of topoisomerase II poisons used in the treatment of leukemia. Blood 2004;103(12):4659-65.

60. Hardcastle IR, Cockcroft X, Curtin NJ, El-Murr MD, Leahy JJJ, Stockley M, Golding BT, Rigoreau L, Richardson C, Smith GCM, Griffin RJ. Discovery of potent chromen-4-one inhibitors of the DNAdependent protein kinase (DNA-PK) using a small-molecule library approach. J Med Chem 2005;48(24):7829-46.

61. Zhao Y, Thomas HD, Batey MA, Cowell IG, Richardson CJ, Griffin RJ, Calvert AH, Newell DR, Smith GCM, Curtin NJ. Preclinical evaluation of a potent novel DNA-dependent protein kinase inhibitor NU7441. Cancer Res 2006;66(10):5354-62.

62. Tavecchio M, Munck JM, Cano C, Newell DR, Curtin NJ. Further characterisation of the cellular activity of the DNA-PK inhibitor, NU7441, reveals potential cross-talk with homologous recombination. Cancer Chemother Pharmacol 2012;69(1):155-64.

63. Tsuji T, Sapinoso L, Sankar S, Mortensen DS, Xu S. 306 CC-115 inhibits DNA damage and repair pathways in vitro. In: Egermont AM, editor. European Journal of Cancer. Proceedings of the $26^{\text {th }}$ EORTC - NCl AACR Symposium on Molecular Targets and Cancer Therapeutics; 2014, 18-21 November; Barcelona, Spain. Oxford: Elsevier; 2014. p. 100.

64. Mortensen DS, Fultz KE, Xu W, Tsuji T, Hickman M, Abbasian M, Khambatta G, Cathers B, Worland P, Moghaddam MF, Apuy J, Richardson S, Elsner J, Shevlin G, Perrin-Ninkovic S, Canan S, Raymon HK, Narla RK, Peng S, Sankar S. 459 Preclinical characterization of CC115 , a novel inhibitor of DNA-PK and mTOR kinase currently under clinical investigation. In: Egermont AM, editor. European Journal of Cancer. Proceedings of the $26^{\text {th }}$ EORTC - NCl - AACR Symposium on Molecular Targets and Cancer Therapeutics; 2014, 18-21 November; Barcelona, Spain. Oxford: Elsevier; 2014. p. 150.

65. Chandra G, Alexander V, Lee HW, Jeong LS. Improved synthesis of a DNA-dependent protein kinase inhibitor IC86621. Arch Pharm Res 2012;35(4):639-45.

66. Sarkaria JN, Busby EC, Tibbetts RS, Roos P, Taya Y, Karnitz LM, Abraham RT. Inhibition of ATM and ATR Kinase Activities by the Radiosensitizing Agent, Caffeine. Cancer Res 1999;59(17):4375-82.

67. Cortez D. Caffeine inhibits checkpoint responses without inhibiting the ataxia-telangiectasia-mutated (ATM) and ATM- and Rad3-related (ATR) protein kinases. J Biol Chem 2003;278(39):37139-45.

68. Blasina A, Price BD, Turenne GA, McGowan CH. Caffeine inhibits the checkpoint kinase ATM. Curr Biol 1999;9(19):1135-8.

69. Batey MA, Zhao Y, Kyle S, Richardson C, Slade A, Martin NMB, Lau A, Newell DR, Curtin NJ. Preclinical evaluation of a novel ATM inhibitor, KU59403, in vitro and in vivo in p53 functional and dysfunctional models of human cancer. Mol Cancer Ther 2013;12(6):959-67.

70. Hickson I, Zhao Y, Richardson CJ, Green SJ, Martin NMB, Orr Al, Reaper PM, Jackson SP, Curtin NJ, Smith GCM. Identification and Characterization of a Novel and Specific Inhibitor of the AtaxiaTelangiectasia Mutated Kinase ATM. Cancer Res 2004;64(24):9152-9.

71. Shaheen FS, Znojek P, Fisher A, Webster M, Plummer R, Gaughan L, Smith GCM, Leung HY, Curtin NJ, Robson CN. Targeting the DNA double strand break repair machinery in prostate cancer. PLoS ONE 2011;6(5):e20311.

72. Golding SE, Rosenberg E, Valerie N, Hussaini I, Frigerio M, Cockcroft XF, Chong WY, Hummersone M, Rigoreau L, Menear KA, O'Connor MJ, Povirk LF, van Meter T, Valerie K. Improved ATM kinase inhibitor KU-60019 radiosensitizes glioma cells, compromises insulin, AKT and ERK prosurvival signaling, and inhibits migration and invasion. Mol Cancer Ther 2009;8(10):2894-902.

73. Golding SE, Rosenberg E, Adams BR, Wignarajah S, Beckta JM O'Connor MJ, Valerie K. Dynamic inhibition of ATM kinase provides a strategy for glioblastoma multiforme radiosensitization and growth control. Cell Cycle 2012;11(6):1167-73.

74. White JS, Choi S, Bakkenist CJ. Transient ATM kinase inhibition disrupts DNA damage-induced sister chromatid exchange. Sci Signal 2010;3(124):ra44.

75. White JS, Choi S, Bakkenist CJ. Irreversible chromosome damage accumulates rapidly in the absence of ATM kinase activity. Cell Cycle 2008;7(9):1277-84.

76. Rainey MD, Charlton ME, Stanton RV, Kastan MB. Transient inhibition of ATM kinase is sufficient to enhance cellular sensitivity to lonizing Radiation. Cancer Res 2008;68(18):7466-74.

77. Wang $H$, Zuo B, Wang H, Ren L, Yang P, Zeng M, Duan D, Liu C, Li M. CGK733 enhances multinucleated cell formation and cytotoxicity induced by taxol in Chk1-deficient HBV-positive hepatocellular carcinoma cells. Biochem Biophys Res Commun 2012;422(1):103-8.

78. Harrison LRE, Ottley CJ, Pearson DG, Roche C, Wedge SR, Dolan ME, Newell DR, Tilby MJ. The kinase inhibitor O6cyclohexylmethylguanine (NU2058) potentiates the cytotoxicity of cisplatin by mechanisms that are independent of its effect upon CDK2. Biochem Pharmacol 2009;77(10):1586-92.

79. Peasland A, Wang L-Z, Rowling E, Kyle S, Chen T, Hopkins A, Cliby WA, Sarkaria J, Beale G, Edmondson RJ, Curtin NJ. Identification and evaluation of a potent novel ATR inhibitor, NU6027, in breast and ovarian cancer cell lines. Br J Cancer 2011;105(3):372-81.

80. Sultana R, Abdel-Fatah T, Perry C, Moseley P, Albarakti N, Mohan V, Seedhouse C, Chan S, Madhusudan S. Ataxia Telangiectasia Mutated and Rad3 Related (ATR) Protein Kinase Inhibition Is Synthetically Lethal in XRCC1 Deficient Ovarian Cancer Cells. PLoS ONE 2013;8(2):e57098.

81. Liu GT. Pharmacological actions and clinical use of fructus schizandrae. Chin Med J 1989;102(10):740-9.

82. Nishida H, Tatewaki N, Nakajima Y, Magara T, Ko KM, Hamamori Y, Konishi T. Inhibition of ATR protein kinase activity by schisandrin B in DNA damage response. Nucl Acids Res 2009;37(17):5678-89.

83. Tatewaki N, Nishida H, Yoshida M, Ando H, Kondo S, Sakamaki T, Konishi T. Differential effect of schisandrin B stereoisomers on ATR-mediated DNA damage checkpoint signaling. J Pharmacol Sci 2013;122(2):138-48.

84. Li L, Lu Q, Shen Y, Hu X. Schisandrin B enhances doxorubicin-induced 
apoptosis of cancer cells but not normal cells. Biochem Pharmacol 2006;71(5):584-95.

85. Reaper PM, Griffiths MR, Long JM, Charrier J-D, Maccormick S, Charlton PA, Golec JMC, Pollard JR. Selective killing of ATM- or p53-deficient cancer cells through inhibition of ATR. Nat Chem Bio 2011;7(7):428-30.

86. Vávrová J, Zárybnická L, Lukášová E, Řezáčová $M$, Novotná $E$, Sinkorová Z, Tichý A, Pejchal J, Durišová K. Inhibition of ATR kinase with the selective inhibitor VE-821 results in radiosensitization of cells of promyelocytic leukaemia (HL-60). Radiat Environ Biophys 2013;52(4):471-9.

87. Charrier J-D, Durrant SJ, Golec JMC, Kay DP, Knegtel RMA, MacCormick S, Mortimore M, O'Donnell ME, Pinder JL, Reaper PM, Rutherford AP, Wang PSH, Young SC, Pollard JR. Discovery of potent and selective inhibitors of ataxia telangiectasia mutated and Rad3 related (ATR) protein kinase as potential anticancer agents. J Med Chem 2011:54(7):2320-30.

88. Fokas E, Prevo R, Pollard JR, Reaper PM, Charlton PA, Cornelissen B, Vallis KA, Hammond EM, Olcina MM, Gillies McKenna W, Muschel RJ, Brunner TB. Targeting ATR in vivo using the novel inhibitor VE-822 results in selective sensitization of pancreatic tumors to radiation. Cell Death Dis 2012;3:e441.

89. Foote KM, Blades K, Cronin A, Fillery S, Guichard SS, Hassall L, Hickson I, Jacq X, Jewsbury PJ, McGuire TM, Nissink JWM, Odedra R, Page K, Perkins P, Suleman A, Tam K, Thommes P, Broadhurst R, Wood C. Discovery of 4-\{4-[(3R)-3-Methylmorpholin-4-yl]-6-[1(methylsulfonyl)cyclopropyl]pyrimidin-2-yl\}-1H-indole (AZ20): a potent and selective inhibitor of ATR protein kinase with monotherapy in vivo antitumor activity. J Med Chem 2013;56(5):2125-38.

90. Jones CD, Blades K, Foote KM, Guichard SM, Jewsbury PJ, McGuire T, Nissink JW, Odedra R, Tam K, Thommes P, Turner P, Wilkinson G, Wood C, Yates JW. Abstract 2348: Discovery of AZD6738, a potent and selective inhibitor with the potential to test the clinical efficacy of ATR kinase inhibition in cancer patients. In: Prendergast GC, editor. The Journal of Cancer Research. Proceedings of the AACR 104th Annua Meeting 2013; 2013, 06-10 April; Washington DC, USA. Philadelphia: AACR; 2013. p. 2348.

91. Pastwa E, Poplawski T, Lewandowska U, Somiari SB, Blasiak J, Somiari RI. Wortmannin potentiates the combined effect of etoposide and cisplatin in human glioma cells. Int J Biochem Cell Biol 2014;53:42331.

92. Zhao J-X, Liu H, Lv J, Yang X-J. Wortmannin enhances cisplatin-induced apoptosis in human ovarian cancer cells in vitro. Eur Rev Med Pharmacol Sci 2014;18(17):2428-34.

93. Carminati PO, Donaires FS, Marques MM, Donadi EA, Passos G a. S, Sakamoto-Hojo ET. Cisplatin associated with LY294002 increases cytotoxicity and induces changes in transcript profiles of glioblastoma cells. Mol Biol Rep 2014;41(1):165-77.
94. Kruszewski M, Wojewódzka M, Iwaneńko T, Szumiel I, Okuyama A. Differential inhibitory effect of OK-1035 on DNA repair in L5178Y murine lymphoma sublines with functional or defective repair of double strand breaks. Mutat Res 1998;409(1):31-6.

95. Niazi MT, Mok G, Heravi M, Lee L, Vuong T, Aloyz R, Panasci L, Muanza T. Effects of dna-dependent protein kinase inhibition by NU7026 on dna repair and cell survival in irradiated gastric cancer cell line N87. Curr Oncol 2014;21(2):91-6.

96. Ciszewski WM, Tavecchio M, Dastych J, Curtin NJ. DNA-PK inhibition by NU7441 sensitizes breast cancer cells to ionizing radiation and doxorubicin. Breast Cancer Res Treat 2014;143(1):47-55.

97. Tichy A, Durisova K, Salovska B, Pejchal J, Zarybnicka L, Vavrova J, Dye NA, Sinkorova Z. Radio-sensitization of human leukaemic MOLT-4 cells by DNA-dependent protein kinase inhibitor, NU7441. Radiat Environ Biophys 2014;53(1):83-92.

98. Alao JP, Sunnerhagen P. The ATM and ATR inhibitors CGK733 and caffeine suppress cyclin D1 levels and inhibit cell proliferation. Radiat Oncol 2009;4(1):51.

99. Cmielova J, Havelek R, Kohlerova R, Soukup T, Bruckova L, Suchanek J, Vavrova J, Mokry J, Rezacova M. The effect of ATM kinase inhibition on the initial response of human dental pulp and periodontal ligament mesenchymal stem cells to ionizing radiation. Int J Radiat Biol 2013;89(7):501-11.

100. Park J, Jo YH, Cho CH, Choe W, Kang I, Baik HH, Yoon K-S. ATMdeficient human fibroblast cells are resistant to low levels of DNA double-strand break induced apoptosis and subsequently undergo drug-induced premature senescence. Biochem Biophys Res Commun 2013;430(1):429-35.

101. Zhu Y, Mao C, Wu J, Li S, Ma R, Cao H, Ji M, Jing C, Tang J. Improved ataxia telangiectasia mutated kinase inhibitor KU60019 provides a promising treatment strategy for non-invasive breast cancer. Oncol Lett 2014;8(5):2043-8.

102. Vecchio D, Daga A, Carra E, Marubbi D, Raso A, Mascelli S, Nozza P, Garrè ML, Pitto F, Ravetti JL, Vagge S, Corvò R, Profumo A, Baio G, Marcello D, Frosina G. Pharmacokinetics, pharmacodynamics and efficacy on pediatric tumors of the glioma radiosensitizer KU60019. Int J Cancer 2015;136(6):1445-57.

103. Salovska B, Fabrik I, Durisova K, Link M, Vavrova J, Rezacova M Tichy A. Radiosensitization of Human Leukemic HL-60 Cells by ATR Kinase Inhibitor (VE-821): Phosphoproteomic Analysis. Int J Mol Sci 2014;15(7):12007-26.

104. Huntoon CJ, Flatten KS, Wahner Hendrickson AE, Huehls AM, Sutor SL, Kaufmann SH, Karnitz LM. ATR Inhibition Broadly Sensitizes Ovarian Cancer Cells to Chemotherapy Independent of BRCA Status. Cancer Res 2013;73(12):3683-91. 